\title{
Evaluation of cashew (Anacardium occidentale) accessions diversity of in large pools of production in Cameroon and their germ performance to increase productivity
}

\author{
Chantal MADOU ${ }^{1}$, SALI Bourou ${ }^{2}$, AWE DJONGMO Victor ${ }^{3}$ and Abraham NOME \\ 1 Institute of Agricultural Research for Development (IRAD), Yaoundé Research Centre. B.P. 2067 Yaoundé, Cameroun. \\ 2 Institute of Agricultural Research for Development (IRAD), Garoua Multipurpose Research Station, B.P. 415, Garoua, \\ Cameroun. \\ 3 Department of Biological Sciences, University of Ngaoundéré. B.P. 454 Ngaoundéré, Cameroon. \\ 4 Institute of Agricultural Research for Development (IRAD), Ngaoundéré Research Centre. B.P. 65 Ngaoundéré, Cameroun. \\ * Auteur correspondent, E-mail : chantal.madou@yahoo.fr
}

Keywords: Diversity, accessions, morphological, Cameroon

Mots clés : Diversité, accessions, morphologique, Cameroun

Publication date 30/11/2020, http://m.elewa.org/Journals/about-japs/

\section{ABSTRACT}

The sector faces many difficulties, in particular the mastery of the different varieties and the germination aptitudes by the planters. This study is therefore a contribution to the characterization of the diversity of cashew accessions in the northern zone of Cameroon as well as their germination performance. Physical characteristics such as: fruit weight, apple length, apple weight, nut weight and length, and seed coat color were assessed in this study.It appears that the morphological characteristics of the fruit vary according to production areas. Analysis of variance confirmed a significant difference in the morphological characteristics of cashew fruit between the four study areas $(P$-value $<0.05)$, except the ratio of the weight apple and nut. The fruits of Ngaoundéré area have the best characteristics in terms of fruit weight $(140.66 \pm 14.24 \mathrm{~g})$, length of head $(75.11 \pm 5.60 \mathrm{~mm})$, the length of nuts $(41,63 \pm 1.34 \mathrm{~mm})$, apple weight $(126.87 \pm 13.99 \mathrm{~mm})$ and nuts weight $(13.78 \pm 0.60 \mathrm{~mm})$. The method of soaking nuts for 48 hours in plain water is a technique that provides a waiting time of 8 to 15 days before the start of germination, with a germination period of between 11-23 days and a germination rate of 90 to $100 \%$.

The results recorded showed a fairly good germination capacity of the seeds resulting from the various pretreatments. The mastery of these germination techniques is essential to improve the production of nurseries.

\section{RESUME}

L'anacardier occupe une place importante dans l'économie du Cameroun. La filière est confrontée cependant à un certain nombre de difficultés, notamment la méconnaissance des caractéristiques des différentes variétés par les producteurs. Cette étude est donc une contribution à la caractérisation des anacardiers présents dans la zone septentrionale du Cameroun. Les caractéristiques morphologiques (poids du fruit, longueur de la pomme, poids de la pomme, poids et longueur de la noix) ont été évaluées. Il ressort que ces caractéristiques varient en fonction des bassins de productions. L'analyse de variance atteste 
une différence significative des caractéristiques morphologiques des fruits d'anacardes entre les quatre zones d'études $(P$-value $<0,05)$, excepté le rapport entre le poids de la pomme et de la noix. Les fruits de la zone Ngaoundéré présentent les meilleures caractéristiques en termes du poids fruits $(140,66 \pm 14,24 \mathrm{~g})$, de la longueur de pomme $(75,11 \pm 5,60 \mathrm{~mm})$, de la longueur de noix $(41,63 \pm 1,34 \mathrm{~mm})$, du poids de pomme $(126,87 \pm 13,99 \mathrm{~mm})$ et du poids de noix $(13,78$ $\pm 0,60 \mathrm{~mm})$. La méthode de trempage des noix pendant 48 heurs dans de l'eau ordinaire est une technique qui permet d'obtenir une durée d'attente allant de 8 à 15 jours avant le début de la germination, avec un délai de germination variant entre 11 à 23 jours et un taux germination de 90 à $100 \%$. Les résultats obtenus ont montré une assez bonne aptitude à la germination des semences issues des différents prétraitements. La connaissance de ces techniques est fondamentale pour tout programme d'amélioration de la production des pépinières.

\section{INTRODUCTION}

The cashew (Anacardium occidentale L.) is a tree whose production contribute to the socioeconomic development of many countries (Martin, 2002; Marlos et al., 2007). This plant is originated from Brazil (Trevian et al., 2005), was introduced in East Africa and India in the sixteenth century by the Portuguese (Martin et al., 1997). The cashew tree is a tropical tree fast growing, it can get up to 6 to $12 \mathrm{~m}$ high and 20 $\mathrm{m}$ times (Coly, 2017; Niang, 2017). They are found in the Caribbean, north-east Brazil (Djaha et al, 2012), Asia and Africa within isohyets between 500 and $4000 \mathrm{~mm}$. Their main interest lies in the production of nuts which remains an economic activity for many tropical countries (Lemaitre, 2003). The products are used in many areas including food processing (Soro, 2012), cosmetics (Rongaed, 2018), medicine (Macou, 2014) and industries (Abreu, 2005). the first trees were planted to fight against erosion and rigger hedgerows to protect farms against damage caused by the horses (Guma, 2003). So either almond or cashew apple were valued and consumed locally until recent years (Konan, 2010

In Cameroon, the cashew tree is a fruit tree of known advantage. It was introduced by the National Rural Development Fund (FONADER) in 1972 (Anonymous, 2016). However, its culture is only favorable to the three northern regions of the country namely Adamawa, the North and the Far North. Currently, due to growing demand, its cultivation is spreading to other regions such as the eastern and central parts of the country (Hamawa et al., 2019).

However, the sector suffers from enormous difficulties due to the use of marginal varieties, poor agricultural practices and maintenance of plantations (Ndiaye et al., 2017). Studies have shown that performance of the cashew tree varies by country: 400 to $600 \mathrm{~kg} / \mathrm{ha}$ in India and East Africa, 200 to $400 \mathrm{~kg} / \mathrm{ha}$ in West Africa (Pasa, 1994). In Senegal, with an estimated annual production of raw nuts to 17522 tons (Padec, 2016), yields range from $250 \mathrm{~kg} / \mathrm{ha}$ to $400 \mathrm{~kg} / \mathrm{ha}$ (Ndiaye et al., 2017). This varies depending on the climate (Bello et al., 2017), variety (Djaha et al., 2014), the soil fertility (Nortcliff and Gregory, 2013) cultivation practices and maintenance orchards (Koffi and Bamba, 2008) incompatibility pollen during fertilization (Aliyu and Awopetu, 2007). Otherwise, very little work has been done on this species in Cameroon, as well as on production processing. In recent years this cultivation of cashew nuts has grown in importance in the rural northern part of the. This enthusiasm is even more striking among policy makers and researchers to which the sector has been gaining more attention. SODECOTON (Cotton Development Company) through the Institute of Agricultural Research for Development (IRAD), intends to strengthen Cameroon's cotton industry by integrating the culture of cashew to cotton. This in order to contribute to 
the socioeconomic development of the farmers and environmental protection. Hence the need to initiate research work to better control the morphological diversity of cashew trees in the north. This study aims to: (i) to characterize the

\section{MATERIALS AND METHODS}

3.1 Site Study: The study was conducted Kismatari experimental orchard located about $6 \mathrm{~km}$ from the multipurpose Research Station Garoua. Geographic coordinates are: Latitude: 9 - 19'N, Longitude: $13{ }^{\circ} 28^{\prime} \mathrm{E}$, Altitude: 180 meters. The plant material of the study consists of seeds and fruits of cashew nuts from four production areas: Yagoua, Touboro, Ngaoundéré and Garoua. These nuts were collected in February 2019 in farmers plantations. The collection of nuts and cashew fruit was to select ten feet by ten field on which fruits were collected and brought back to the laboratory for morphological characterization. Nuts were dried and stored at room temperature in the laboratory. morphological traits of the accessions of four pools of cashew production (Yagoua, Touboro, Ngaoundéré and Garoua) grown in Cameroon and (ii) evaluate the germination behaviour of nuts of these varieties in the nursery.

\subsection{Morphological characterization of} cashew fruit: The variables considered in the assessment of the morphology of apples and cashew nuts in this study are the length, width and weight. Measuring dimensions was carried out by means of a foot to mark slide (Stainless Hardened) by the method of Silou (1996) described by Diakabana et al. (2013). The determination of the mass of apples and cashew nuts were made using a sensitive balance (Manlloro) measured by the method of Diakabana et al. (2013) described by Massengo et al. (2014). Determining the Apple / Nuts ratio is a measure of determining the mass of the fresh apple cashew nut, ground nut and fresh apple ratio / nuts in order to justify the importance weight of apples morphotypes cashew considered by products of nuts farm.

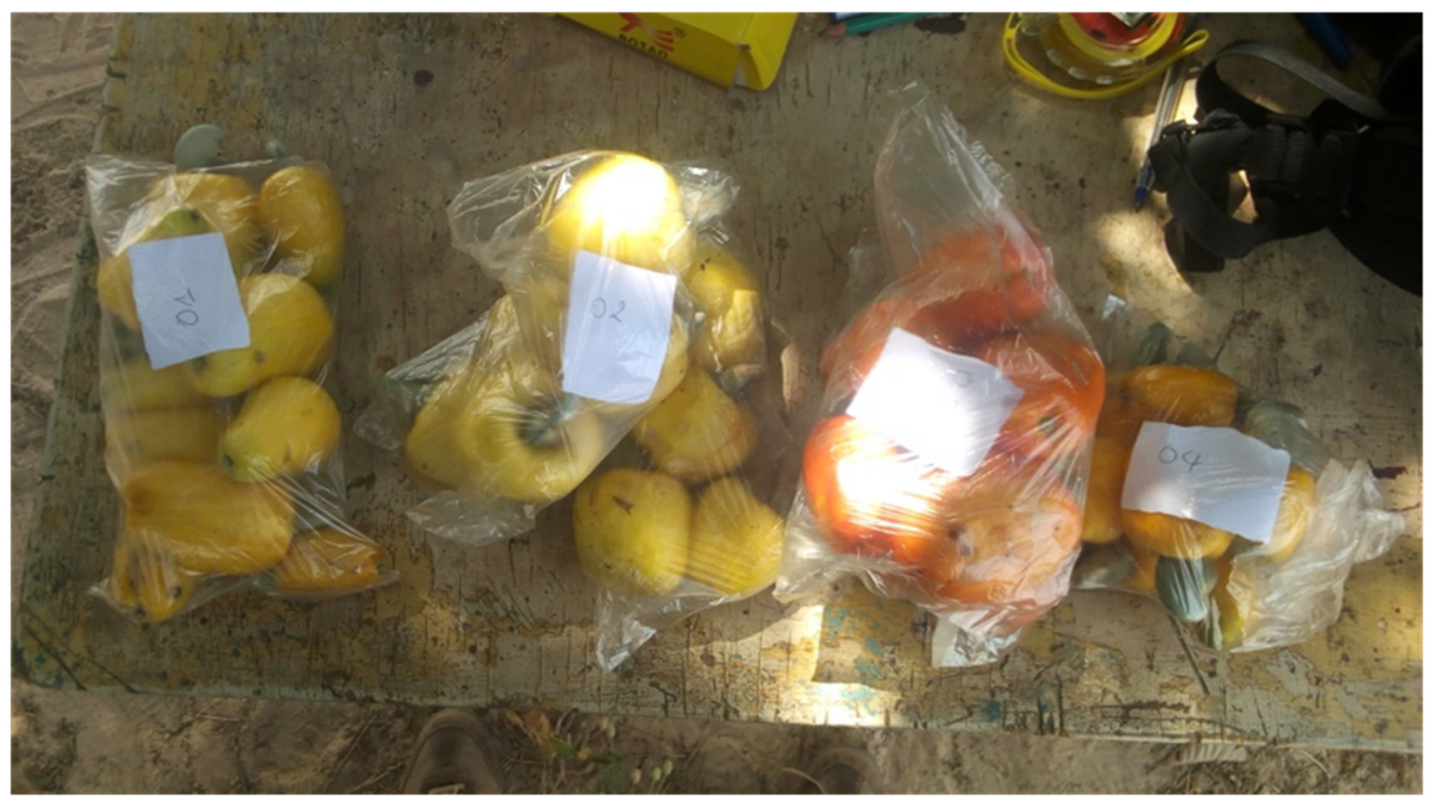

Figure 1: Pictures showing the variability of the colour and shape of cashew fruits

3.3 Flotation test of cashew trees: The Protocol on the dormancy of cashews was prepared using information gathered from cashew's producers surveyed and from the literature review. Before applying these methods, seed quality was evaluated by flotation technique 
(Hamawa et al., 2019). Initially, two floats tests were experienced and nuts were immersed in three times the volume of water.

3.3.1 During the first flotation test: Good nuts were separated from bad in the dipping into a vessel containing brine $(1 \mathrm{~kg}$ of cooking salt in 10 litres of water). After 6 hours, the nuts that float were eliminated (alleged poor quality) and those which remained in the bottom of the container were selected (good seed).

3.3.2 The second flotation test: The nuts were introduced in the bucket fill with ordinary water at room temperature, those that flow were used while those that float were set aside. The floating nut floats from both tests were also used for sowing in order to assess the viability of the two tests. Accordingly, 20 nuts were taken randomly for each case to be sown.

3.4 Application of pre-treatments cashew trees: The application of pre-treatments on cashew nuts aimed at speeding germination and get a room homogeneous nucleation. As part of this study six pre-treatments were applied to the nuts of the four raised origins.

\section{- 3.4.1 Method 1: Mechanical treatment}

The nuts were scarified by scratching each seed with sandpaper (Ndour, 1997).

\section{- 3.4.2 Method 2: Dipping in water at room temperature}

The nuts were soaked directly in water at room temperature for 48 hours and the soaking water was renewed every six (6) hours (Djaha et al., 2008).

\section{- $\quad$ 3.4.3 Method 3: Soaking in boiling water and cool}

The nuts were immersed in boiling water until the water has cooled (Jaouadi et al., 2010).

\section{- $\quad$ 3.4.4 Method 4: Soaking with brine}

A salt $0.5 \mathrm{~kg}$ mass were dissolved in a container containing 10 litres of water and the nuts were then poured inside. The nuts were left for 24 hours in the soaking water.

\section{- 3.4.5 Method 5: Soaking in boiling water for 10 seconds;}

The nuts were immersed in boiling water for 10 seconds. The volume of water was approximately twice that of the seeds to the water to cool quickly. Method 6: Without any treatment (control group). Nuts from each were taken from risky way and sown without treatment.

3.5 Sowing pre-treated nuts: The test was conducted according to an experimental device in complete randomized block with two factors. The factors studied was the sources (03) and pretreatments (06), of 04 repetitions. The nuts were sown in February 2019, in a substrate composed of loam, sand and manure in equal proportions $(1 / 3 ; 1 / 3$ and $1 / 3)$. This substrate was placed in pots of $30 \mathrm{~cm}$ of long, $15 \mathrm{~cm}$ wide and $0.3 \mathrm{~mm}$ thick, perforated on the sides and at the base. The nuts were embedded in the wet substrate prior to $5 \mathrm{~cm}$ deep, with the peduncle upwardly initially and in a second stage seeding was carried out in the opposite direction (downwardly peduncle). In front of each board, a panel was expected to register the different treatments. Watering was done once a day, preferably early in the morning or late in the day, until emergence of plant. Shading was maintained until the seedlings have 3-4 leaves and then they were gradually acclimatized. In terms of plant maintenance, the nursery has been frequently treated with insecticide-fungicide (Imidacloprid $(250 \mathrm{~g} / \mathrm{kg})$ and Thirame $(200 \mathrm{~g} / \mathrm{kg})$ to fight against fungi that attack young plants at ground level.

3.6 Parameters to be observed before, at the beginning and during the germination process:

$>\quad$ Start date of germination (DAS) or the waiting time is defined as the time elapsed between sowing and first germination,

$>\quad$ germination period (day) or germination time is defined as the time between the first and last germination

$>$ Germination rate $(\%)$ is defined as the ratio between the number of seeds germinated $(\mathrm{G})$ and the number of seeds sown $(\mathrm{N})$ (Hamawa et al., 2019).

$>\quad$ Graining (number of nuts / kg) 
3.7 Parameters to be observed in terms of vigour seedlings, 70 days after sowing (DAS) (Djaha et al., 2010)

$$
\begin{array}{ll}
\checkmark & \text { Height }(\mathrm{cm}) \\
\checkmark & \text { Diameter }(\mathrm{cm}) \\
\checkmark & \text { Number of sheets }
\end{array}
$$

3.8 Statistical analysis: The parameters recorded were analysed like a descriptive statistic in Microsoft Excel 2010. One-way analysis of

\section{$4 \quad$ RESULTS}

4.1 Physical and morphological characterization of cashew trees: Four different colours of apple have been identified in variance (ANOVA) at a significance level of 0.05 was applied and all data shown in tables are means \pm standard errors (Djaha et al., 2010). The Post-hoc tests (Duncan test) of means were used to separate all groups according to each factor. They were then subjected to principal components analysis (PCA) (Djaha et al., 2014). All statistical analyses were performed in STATISTICA 7.

the field, namely: yellow (c) pale yellow (d), orange-red (a) and red (b) (Figure 2).

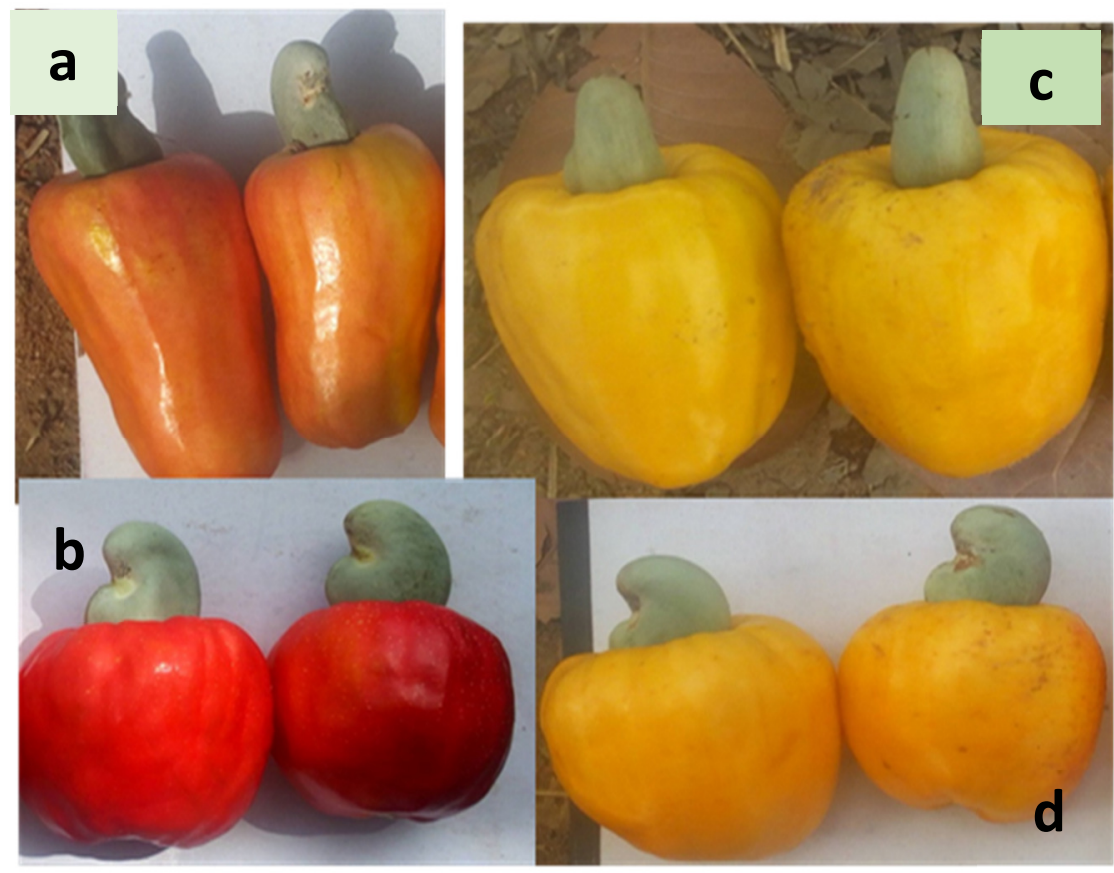

Figure 2: Variability of the colour and shape of the fruits of cashew

Examination of the results shows that the characteristics of the fruit vary from study areas (Table 1). The fruits of Ngaoundéré area have the best characteristics in terms of fruit weight $(140.66 \pm 14.24 \mathrm{~g})$, apple length $(75.11 \pm 5.60$ $\mathrm{mm})$, The length of nut $(41.63 \pm 1.34 \mathrm{~mm})$, Apple weight $(126.87 \pm 13.99 \mathrm{~mm})$ and walnut weight $(13.78 \pm 0.60 \mathrm{~mm})$. It emerges, however, in terms of ratio between the weight of apples and walnuts, fruit Garoua the area with the lowest ratio $(8.4 \pm 0.33)$, while those of the Touboro area have the highest ratio $(9.32 \pm$ 0.31). Variance analysis confirms a significant difference morphological characteristics of cashew fruit among the four study areas (P-value $<0.05$ ), except the ratio of the weight of the apple and walnuts. 
Table 1: Morphological characteristics of cashew trees.

\begin{tabular}{l|c|c|c|c|c|c}
\hline Areas & PTO $\mathbf{( g )}$ & LOP $\mathbf{( m m})$ & Lon $\mathbf{( m m )}$ & PdP (g) & PdN (g) & POP / PdN \\
\hline Garoua & $40.92 \pm 1.70^{\mathrm{a}}$ & $43.18 \pm 1.16^{\mathrm{b}}$ & $29.66 \pm 0.24^{\mathrm{a}}$ & $36.54 \pm 1.62^{\mathrm{a}}$ & $4.38 \pm 0.08^{\mathrm{a}}$ & $8.4 \pm 0.33^{\mathrm{a}}$ \\
Yagoua & $44.50 \pm 2.20^{\mathrm{a}}$ & $48.01 \pm 0.88^{\mathrm{a}}$ & $30.69 \pm 0.27^{\mathrm{a}}$ & $40.07 \pm 2.15^{\mathrm{a}}$ & $4.43 \pm 0.12^{\mathrm{a}}$ & $9.18 \pm 0.48^{\mathrm{a}}$ \\
Touboro & $62.72 \pm 2.46^{\mathrm{b}}$ & $50.06 \pm 1.06^{\mathrm{a}}$ & $30.74 \pm 0.32^{\mathrm{ab}}$ & $56.47 \pm 2.34^{\mathrm{b}}$ & $6.02 \pm 0.13^{\mathrm{b}}$ & $9.32 \pm 0.31^{\mathrm{a}}$ \\
Ngaoundere & $140.66 \pm 45.04^{\mathrm{c}}$ & $75.11 \pm 5.60^{\mathrm{c}}$ & $41.63 \pm 1.34^{\mathrm{c}}$ & $126.87 \pm 13.99 \mathrm{c}$ & $13.78 \pm 0.60^{\mathrm{c}}$ & $9.16 \pm 0.96^{\mathrm{a}}$ \\
\hline P Value & $\mathbf{0 . 0 0}$ & $\mathbf{0 . 0 0 0 0 0}$ & $\mathbf{0 . 0 0}$ & $\mathbf{0 . 0 0}$ & $\mathbf{0 . 0 0}$ & $\mathbf{0 , 3 3}$ \\
\hline
\end{tabular}

PTO: Fruit weight; LOP: apple length; LON: Length of the nuts; POP: apple weight; PdN: Weight of nuts.

Letters assigned on each value: significant differences among study sites (one-way ANOVA, Duncan test on $\alpha 0.05$ )

4.2 Correlation between morphological fruit: Correlation between the characteristics of the fruit has shown that apple related parameters are all correlated (Table 2). The analysis of the relationship between apple characteristics and those of the nuts showed the existence of links. The strongest relationships are obtained between the weight of the nuts with each of the following parameters: weight of apple and fruit weight respectively as correlation $(\mathrm{r}=1 * * *$ and $\mathrm{r}$ $\left.=0.76^{* *}\right)$. More apple is, the more the weight of the nut is too, so we can say that the weight of apples affect the weight of nuts.

Table 2: Correlation matrix between the characteristics of the fruit.

\begin{tabular}{|c|c|c|c|c|c|}
\hline \multirow{2}{*}{$\mathbf{P d} F$} & Pd F & Lo P & Lo N & Pd P & $\mathbf{P d} \mathbf{N}$ \\
\hline & 1.00 & & & & \\
\hline Lo P & 0.76 & 1.00 & & & \\
\hline Lo N & 0.57 & 0.53 & 1.00 & & \\
\hline $\mathbf{P d} \mathbf{P}$ & 1.00 & 0.76 & 0.56 & 1.00 & \\
\hline $\mathbf{P d} \mathbf{N}$ & 0.76 & 0.55 & 0.70 & 0.73 & 1.00 \\
\hline
\end{tabular}

PTO: Fruit weight; LOP: apple length; LON: Length of the nuts; POP: apple weight; PdN: Weight of nuts

4.3 Graining nuts (number of nuts per kilogram): In respect to Figure 3, nuts from Ngaoundéré are large calibre with 116 averages nuts for $1 \mathrm{Kg}$, their mass is more important compared to Yagoua, Touboro and Garoua. Yagoua nuts are of smaller sizes, with 230 averages nuts. This first result leads us to think that nuts from Ngaoundéré would be very interesting for cashew production with the aim of operating nuts. In addition, other parameters such as adaptability and disease resistance are checked.

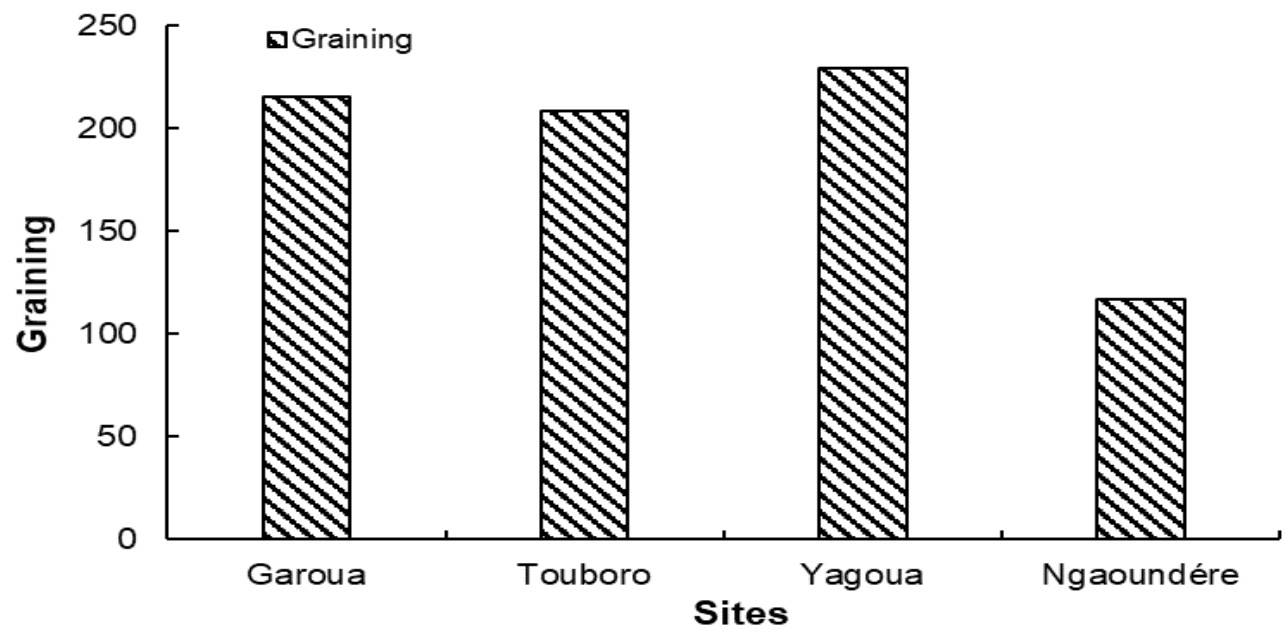

Figure 3: Graining (number of nuts per kilogram) nuts by sites 
4.4 ACP on four sources of cashew fruit: The principal component analysis (PCA) was expressed from two axes which explains the total variability observed (Figures 4). The axis 1, which explained $75.72 \%$ of the total variability was defined by three variables: the length of head (LOP), the weight of the apple (POP) and fruit weight (PTO). These parameters were negatively correlated to the axis (Figure 3 ). The axis 2 , which has translated $12.62 \%$ of the total variability was defined by two variables: the length of the nut (lon) and the weight of the nuts (PdN). This axis was positively correlated to the axis (Figure 4). And which, categorization accessions based on morphological parameters of apple and walnut identified the existence of four groups of accessions (Figure 3). Group 1, 2, potato length, the length of nuts, apple weight and walnut weight. For against Group 4 presents the best characteristics in terms of fruit weight, apple length, the length of nuts, apple and walnut weight weight.

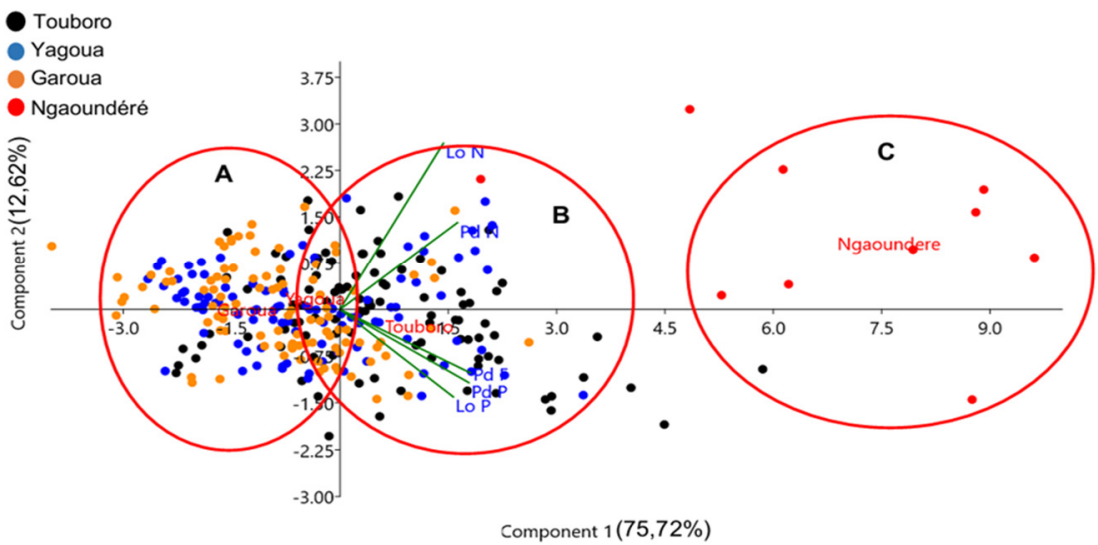

Figure 4: Representation variables in the plane of the axes 1 and 2 of the ACP, according to cashew morphological parameter: PTO: Fruit weight; LOP: apple length; LON: Length of the nuts; POP: apple weight; PdN: Weight of nuts

4.5 Waiting time before the start of germination (DAS) based on pre-treatments: The results of the germination test showed that the recorded wait time varied between 8 and 20 days depending on the pre-treatments applied to nuts, meaning seedlings and regardless of provenance (Figure 5). Considering the six pretreatments associated with the two sowing techniques, the waiting time before the start of germination for nuts sown with the stem pointing downwards, values range from 8 to 20 days and those sown with peduncle upwardly between 15 and 20 days. The waiting time of 8 days corresponds to mechanical treatments (M1), soaking in ordinary water (M2) and soaking in boiling water (M3) represents the minimum value for seeding with peduncle to low. The 15-day corresponds to the treatment by soaking in plain water for 48 hours (M2) for the seedlings with stems up. As for the 20 days waiting period is recorded on the control batch (M6) for planting of two techniques as the maximum value. 


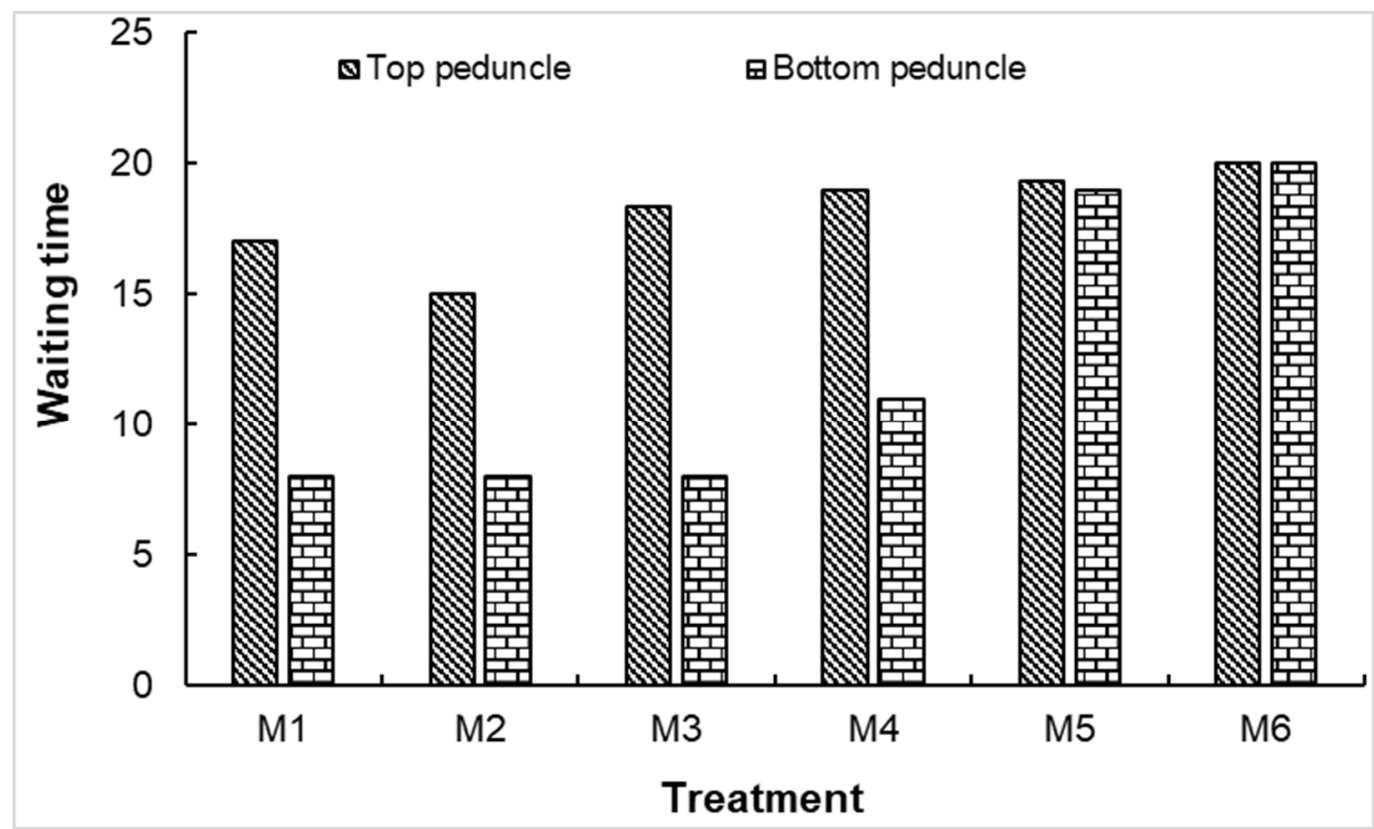

Figure 5: Waiting time between planting and first germination, M1: Mechanical treatment, M2: Soaking ordinary water (48h), M3: Soaking boiling water, M4: Soaking brine, M5: Soaking in boiling water (15 minutes) and M6: witness Lot

4.6 Germination period (Day) based pretreatments: The germination period of 6 nuts from pre-processing is presented in Figure 6. The values of the germination time for planting with the stem facing down range between 10 and
20 days for the respective treatments of M3 and M2. Those of the seedling with the stem facing upwards are 19 and 23 days corresponding to the same treatments.

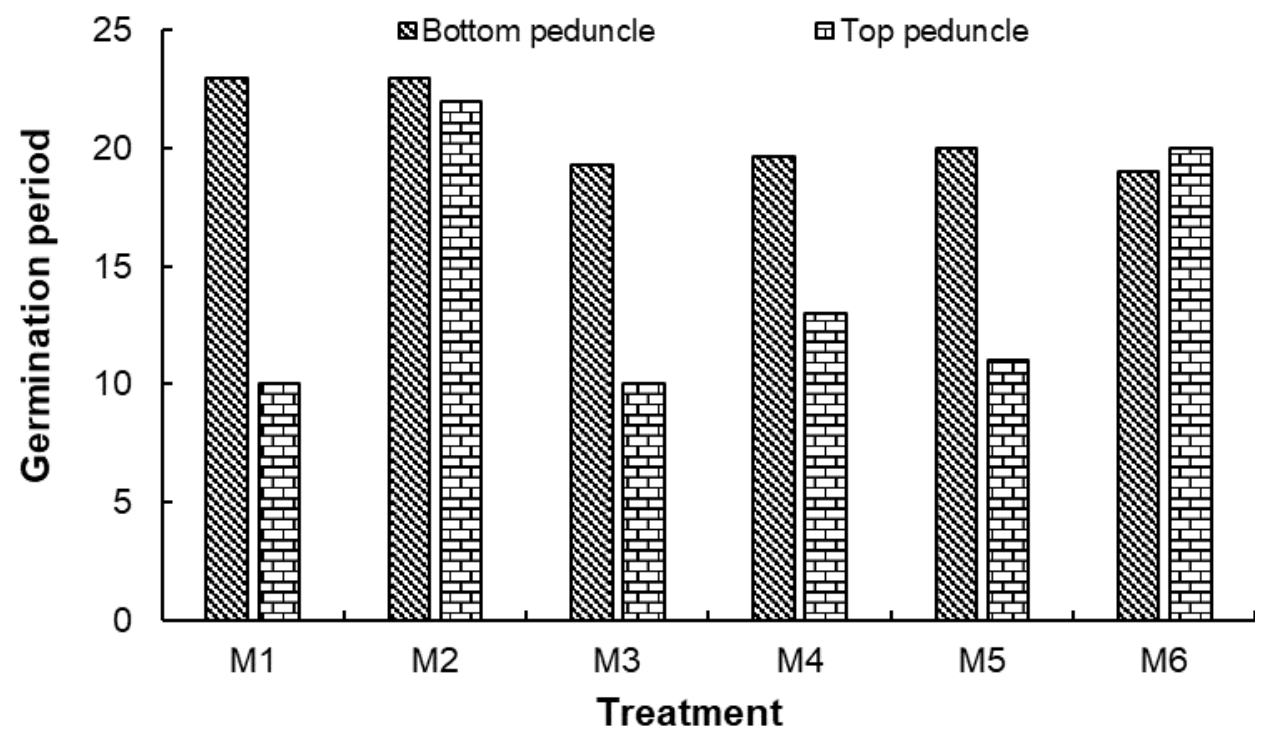

Figure 6: Time between the first and last germination, M1: Mechanical treatment, M2: Soaking cold water, M3: Soaking boiling water, M4: Soaking brine, M5: Soaking in boiling water (15 minutes) and M6: witness Lot 
4.7 Germination rate: Germination varied between 90.16 and $52.16 \%$ for the first direction of seedlings (stem down) (Figure 7). The second direction (upwardly peduncle) between 100 and
$50 \%$. This performance could be explained by pre-treatment but most likely by the quality of nuts sown.

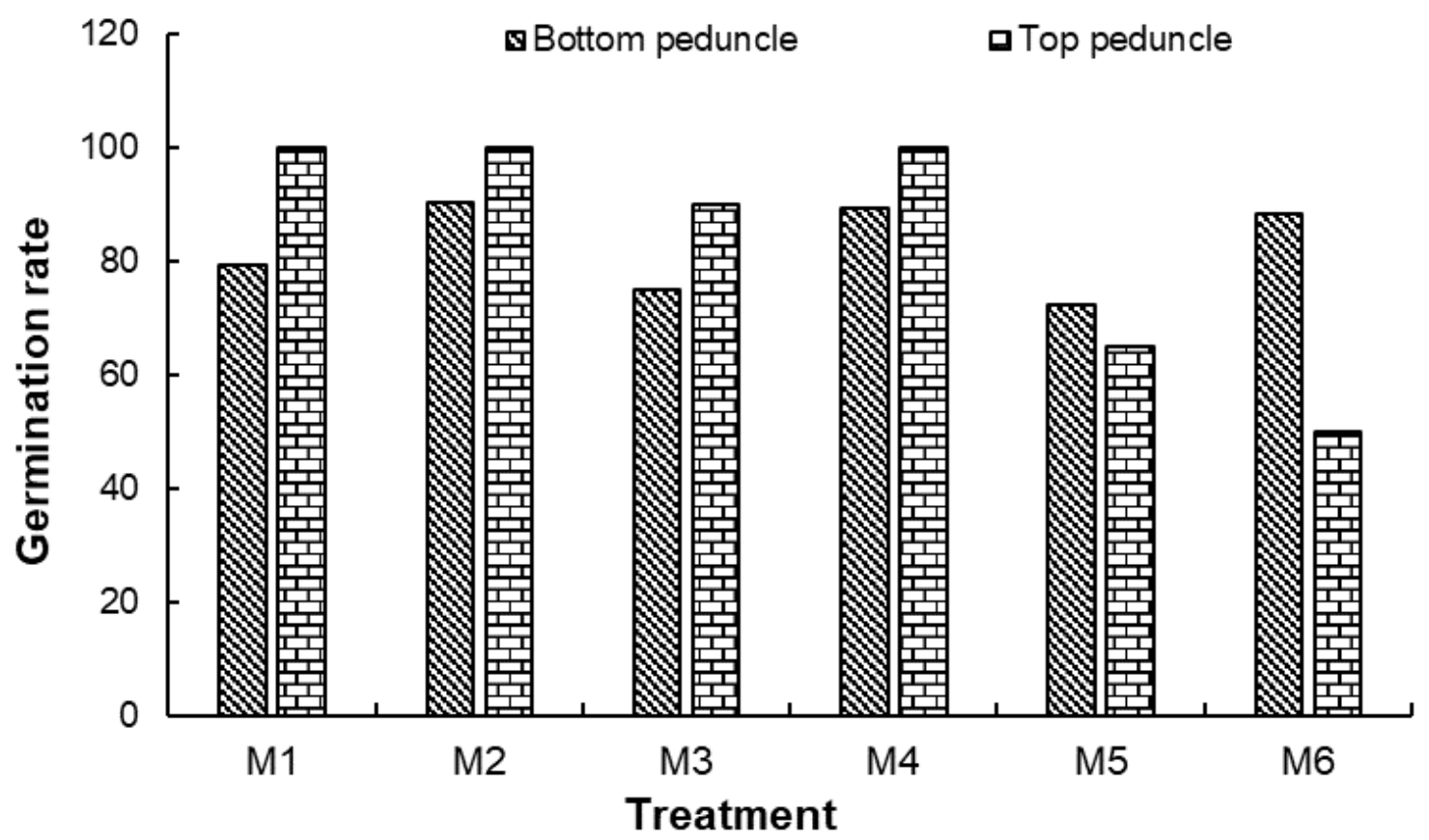

Figure 7: Walnut germination rate by pre-treatments, M1: Mechanical treatment, M2: Soaking cold water, M3: Soaking boiling water, M4: Soaking brine, M5: Soaking in boiling water (15 minutes) and M6: witness Lot

\subsection{Parameters observed according to} production area: The analysis of variance on various parameters such as the waiting time, germination and germination rate not significantly different at the $5 \%$. That said the production area have no effect on the pretreatments and vice versa (Table 3 ).

Table 3: Parameters observed according to the production area (Yagoua, Garoua et Touboro)

\begin{tabular}{l|c|c|c}
\hline & Waiting Time & Duration of Germination & Germination rate \\
\cline { 2 - 4 } Garoua & $17.83 \pm 0.90^{\mathrm{a}}$ & $21.16 \pm 0.90^{\mathrm{a}}$ & $77.75 \pm 8.07^{\mathrm{a}}$ \\
Yagoua & $17.833 \pm 0.30^{\mathrm{a}}$ & $20.33 \pm 1.08^{\mathrm{a}}$ & $82.08 \pm 4.05^{\mathrm{a}}$ \\
Touboro & $17.66 \pm 0.91^{\mathrm{a}}$ & $20.5 \pm 1.02^{\mathrm{a}}$ & $85 \pm 3.22^{\mathrm{a}}$ \\
\hline P value & 0.98 & 0.82 & 0.65 \\
\hline
\end{tabular}

Letters assigned on each value: significant differences among study sites (one-way ANOVA, Duncan test on $\alpha$ 0.05)

4.9 Floatation tests: Table 4 presents the results of floating nut germination rate and those immersed in the presence of salt water and regular overall. Note that the nuts that float to the two flotation tests recorded a germination rate of $65 \%$. As for the nuts that deposit, the rate is $60 \%$ in the case of salt water and $100 \%$ in the case of ordinary water. 
Table 4: $\mathrm{t}$ two flotation techniques, $\mathrm{NC}=$ number of floating nuts and $\mathrm{NI}=$ number of emerging nuts

\begin{tabular}{l|c|c|c|c}
\hline \multirow{2}{*}{ Test } & \multicolumn{2}{|c|}{ Test saltwater flotation } & \multicolumn{2}{c}{ Test flotation ordinary water } \\
\cline { 2 - 5 } Treatment & NC & NI & NC & NI \\
Germination rate $(\%)$ & 65 & 60 & 65 & 100 \\
\hline
\end{tabular}

\subsection{Evolution of growth parameters by} different methods between two sites: Plant height (Ped top) ranged from $12.3 \pm 2.40$ at $18.65 \pm 4.39 \mathrm{~cm}$ with a maximum value obtained for Method 1 (M1). Against by plant height (Ped bottom) fluctuated between $24.1 \pm 4.99$ and $48.55 \pm 78.51 \mathrm{~cm}$ with a highest value recorded for method 5 (M5). The ANOVA revealed that the difference in growth in terms of height for plants (Ped top) is significant $(\mathrm{P}=0.03)$. By cons in plants (Ped down), it is not significant $(\mathrm{P}=$ 0.51). The ANOVA revealed that the difference in growth in terms of collar diameter for plants (Ped top) is not significant ( $\mathrm{P}=0.44)$. For against at plants with (ped bottom), it is significant $(\mathrm{P}=$ 0.000 ) with significant value recorded for method 6 (M6). No change is attested by the ANOVA test in terms of the number of leaf plants (Ped top) ( $\mathrm{P}=0.33)$ and (Ped bottom) $(\mathrm{P}$ $=0.08$; Table 5).

Table 5: Parameters according to seedlings vigour, 70 days after sowing (DAS)

\begin{tabular}{lcccccc}
\hline & \multicolumn{2}{c}{$\begin{array}{c}\text { Height } \\
(\mathbf{C m})\end{array}$} & $\begin{array}{c}\text { Collar diameter } \\
(\mathbf{m m})\end{array}$ & \multicolumn{2}{c}{ Number of leaves } \\
\cline { 2 - 6 } Method & Ped top & Ped down & Ped top & Ped down & Ped top & Ped down \\
\cline { 2 - 7 } M1 & $18.65 \pm 1.39^{\mathrm{b}}$ & $26.55 \pm 1.10^{\mathrm{a}}$ & $4.3 \pm 0.48^{\mathrm{a}}$ & $11.66 \pm 2.10^{\mathrm{b}}$ & $7.2 \pm 2.44^{\mathrm{a}}$ & $9.2 \pm 0.63^{\mathrm{a}}$ \\
M2 & $12.3 \pm 1.40^{\mathrm{b}}$ & $27.7 \pm 1.30^{\mathrm{a}}$ & $4.9 \pm 1.19^{\mathrm{a}}$ & $7.83 \pm 0.98^{\mathrm{a}}$ & $6.9 \pm 2.33^{\mathrm{a}}$ & $8.7 \pm 1.33^{\mathrm{a}}$ \\
M3 & $15.9 \pm 1.12 \mathrm{a}^{\mathrm{b}}$ & $25.25 \pm 1.510^{\mathrm{a}}$ & $4.8 \pm 1.03^{\mathrm{a}}$ & $7.82 \pm 0.86^{\mathrm{a}}$ & $6.5 \pm 2.27^{\mathrm{a}}$ & $9.1 \pm 1.52^{\mathrm{a}}$ \\
M4 & $12.8 \pm 1.96^{\mathrm{a}}$ & $24.1 \pm 1.58^{\mathrm{a}}$ & $4.8 \pm 1.03^{\mathrm{a}}$ & $6.701 \pm 1.39^{\mathrm{a}}$ & $8.1 \pm 1.91^{\mathrm{a}}$ & $7.8 \pm 1.13^{\mathrm{a}}$ \\
M5 & $12.4 \pm 1.37^{\mathrm{a}}$ & $23.77 \pm 1.84^{\mathrm{a}}$ & $4.8 \pm 1.31^{\mathrm{a}}$ & $6.15 \pm 1.51^{\mathrm{a}}$ & $7.2 \pm 1.54^{\mathrm{a}}$ & $8.3 \pm 1.05^{\mathrm{a}}$ \\
M6 & $15.8 \pm 1.41^{\mathrm{ab}}$ & $24.2 \pm 1.04^{\mathrm{a}}$ & $4.7 \pm 1.05^{\mathrm{a}}$ & $12.16 \pm 3.58^{\mathrm{b}}$ & $6.8 \pm 1.93^{\mathrm{a}}$ & $8.6 \pm 0.96^{\mathrm{a}}$ \\
\hline P Value & $\mathbf{0 . 0 3}$ & 0.51 & 0.44 & $\mathbf{0 . 0 0}$ & 0.33 & $\mathbf{0 . 0 8}$ \\
\hline
\end{tabular}

Letters assigned on each value: significant differences among study sites (one-way ANOVA, Duncan test on $\alpha$ 0.05); Ped: peduncle

\section{$5 \quad$ DISCUSSION}

The cashew fruit cultivated in Cameroon display a morphological variability in the apple as well at the nut. Since morphological appearance is the first step of the characterization. The collection of nuts and cashew fruit was characterized at the research station IRAD Garoua. This morphological characterization has highlighted significant differences among all parameters analysed (fruit weight, apple length, nut length, weight apple and nut, collar diameter and number of sheets). All this evidence of a large variability within accessions collection was agree by Castro et al. (2011) research which showed a large phenotypic variability between and within specific in the study of morphological variability cashew in Brazilian savannah. Those morphological variability may be attributed to various factors such as the difference in geographical origin of accessions, human selection and adaptation to new agro-ecological conditions. Like observed in Malawi (Chipojola et al., 2009). The values obtained for the weight of the apples in this study are lower than those mentioned by Gbohaïda et al. (2015) from central and north-east of Benin. They are, however, greater than the value evoked by Sika Chabi et al. (2013) for all varieties of Benin. The comparison with the characteristics of the apples from other regions shows that the observed values of the length of head are correspond to those reported by Rickson and Rickson (1998) and Arshak et al. (2003). They are against lower than those mentioned by Marlos et al. (2007). The weight values are found in the range of 20 
to $160 \mathrm{~g}$ identified by Marlos et al. (2007). However, they are greater than the range of 10 to $72.8 \mathrm{~g}$ advanced by Arshak et al. (2003). The values noted of the weight of the nuts ranging between $4.38 \pm 0.085$ and $13.78 \pm 0.60 \mathrm{~g}$ are different presented by Marlos et al. (2007) and Toure et al (2018). But they are higher than those determined by Chabi Sika et al. (2013) and by O'Farrell et al. (2000). The nuts have a high weight according to the classification of IBPGR (1986) who considers high a value between 7 and $8 \mathrm{~g}$. These differences among authors may be related to the soil characteristics of the study environment and the weather. Indeed, the optimal cultivation of cashew depends on soil type and rainfall Soro. (2012). All these positive correlations reflect the fact that both parameters compared to both move in the same direction. Also the different results obtained demonstrate that the appropriate direction for planting nuts is that the orientation of the stalk down evoked by Lefebvre, (1969). Under the conditions of this study experiment, the smallest values in terms of germination were beginning 8 (day after

\section{CONCLUSION}

In Cameroon, the cashew nut tree is an opportunity to diversify sources of income for producers, thus contributing to the improvement of their living conditions. However, several constraints are an obstacle to the development of this sector. Among these constraints we can mention the poor quality of nuts used for seed, the quality of nuts produced, low productivity varieties and inadequate storage locations nuts in fine the quality material as

\section{ACKNOWLEDGEMENTS}

The authors thank SODECOTON in partnership with IRAD (Agricultural Research Institute for Development) and CIRAD (International Center for Agronomic Research to plant) unlike Lefebvre (1966) who observed 14 days after sowing. It demonstrated that the meaning seedlings influence on the waiting time and the germination rate. The germination rate of between $50 \%$ and $100 \%$ shows that the germination can be high or low depending pretreatments applied- Indeed, the seed or nuts cashew is provided with a hard-outer shell must first be cracked embryo seat (Djaha et al., 2010). According to Gauthier (1991), generally, only after being hydrated the seed swells and softens before the water gets inside to reach the kernel. Considering both directions of sowing, germination rate is high in nuts soaked in water at room temperature for 48 hours between 90.16 to $100 \%$, followed by the method nuts soaked in salt water for 24 hours is 89.1 to $100 \%$. Indeed, Lefebvre (1966) showed that the seed germination rate fluctuates cashew usually between 93 and $98 \%$ in the first months after harvest. The results agree with those of Djaha et al. (2010) who found a germination rate of between $66.6 \%$ and $75 \%$.

varieties. Due to its of the importance in Cameroon, it has become necessary to study the quality of cashew nuts grown in the northern part of Cameroon. First, the size and weight of nuts almonds, have been studied. Secondly, the germination properties and Growth to better understand the factors influencing germination. All these studies will help define adequate technical.

for Development), for the funding granted to the cashew nut component within the framework of this tripartite agreement. 


\section{REFERENCES}

Abreu F, Perez AM, Dornier M. and Reynes M: 2005. Application of cross-flow microfiltration in the production of clarified cashew juice by means of mineral membranes. Fruits 60: 33 - 40.

Arfang O, Kémo G, Siré D, Seydou N, Ngor N. and NDOYE I: 2018. Effet des substrats sur la mycorhization et la croissance de Anacardium occidentale $\mathrm{L}$. en pépinière et des sujets adultes sur les paramètres physico-chimiques du sol Afrique Science $14: 148-159$.

Aliyu OM. and Awopetu ÆJA: 2007. "Assessment of genetic diversity in three populations of cashew (Anacardium occidentale L.)" using proteiniso enzymeelectrophoretic analysis. Genet Resour Crop Evol 54 :1489 - 1497.

Archak S, Gaikwad AB, Gautam D, Rao EVVB, Swamy KRM. and Karihaloo JL: 2003. Comparative assessment of DNA fingerprinting techniques (RAPD, ISSR and AFLP) for genetic analysis of cashew (Anacardium occidentale L.) accessions of India. Genome 46: 362-369.

Bello DO, Ahoton LE, Saidou A, Akponikpe I P B, Ezin va, Balogoun I. and Aho N: 2017. "Climate change and cashew (Anacardium occidentale L.) productivity in Benin (West Africa): perceptions and endogenous measures of adaptation". Int. J. B iol. Chem. Sci. 11924 - 946.

Ndour P : 1997. Comportement de quelques espèces du genre Acacia en condition de stress bydrique et salin simulé. DEA : Biologie végétale, Université Cheikh Anta Diop, Dakar (Sénégal).

Bioget (Action pour la Biodiversité et la Gestion de Terroirs): 2016. (Anacardium occidentale), Fiche technique $\mathrm{N}^{\circ}$ 7.Site web: www. abioget.org.

Castro ACR, Bordallo PN, Cavacanti JJV. and Barros LM: 2011. Brazilian Cashew Germplasm Bank. Plant Genetic Resources, 918: 857-861.

Chabi Sika K, Adoukonou-Sagbadja H, Ahoton LE, Adebo I, Adigoun FA, Saidou A,
Kotchoni SO, Ahanchede A. and BabaMoussa L: 2013. Indigenous knowledge and traditional management of cashew (Anacardium occidentale L.) genetic resources in Benin. J. Exp. Biol. Agric. Sci 1:375-382.

Chipojola FM, Mwase WF, Kwapata MB, Bokosi JM, Nioloma JP. and Maliro MF: 2009. Morphological characterization of cashew (Anacardium occidentale L.) in four populations in Malawi. African Journal of Biotechnology 8: 5173-5181.

Coly ML: 2017. "Etude des caractéristiques morphologiques et de la germination des noix de Anacardium occidentale L. de la région de Ziguinchor", Master, Université de Thiès - Ecole Nationale Supérieure d'Agriculture (ENSA), 57 p.

Soro D: 2012. "Couplage de procédés membranaires pour la clarification et la concentration du jus de pomme de cajou : performances et impacts sur la qualité des produits", Thèse de doctorat, Université de Montpellier Sup Agro, 156 p.

Djaha AJ B, N'da HA, Koffi KE, Adopo AN. and Ake S: 2014. "Diversité morphologique des accessions d'anacardier (Anacardium occidentale 1.) introduits en Côte d'Ivoire" Rev. Ivoir. Sci. Technol 23: 244 - 258.

Djaha JBA, Adopo AAN, Koffi EK, Ballo CK. and Coulibaly M: 2012. Croissance et aptitude au greffage de deux génotypes d'anacardier (Anacardium occidentale L.) élites utilisées comme porte-greffe en Côte d'Ivoire. International Journal of Biological and Chemical Sciences 6:1453 1466.

Djaha JBA, N'guessan A K, Ballo CK. and Ake S: 2010. Germination des semences de deux variétés d'anacardier (Anacardium occidentale L.) élites destinées à servir de porte - greffe en Côte d'Ivoire. Journal of Applied Biosciences 32: 1995 - 2001.

Gbohaïda V, Mossi1 I, Adjou ES, Agbangnan P, Yehouenou BB. and Sohounhloué DCK: 
2015. Morphological and Physicochemical Characterizations of Cashew Apples from Benin for their use as Raw Material in Bioethanol Production. Int. J. Pharm. Sci. Rev. Res 35: 7-11.

IBPGR: (International Board for Plant Genetic Resource) 1986. Descriptors for cashew (Anacardium occidentale L.), Rome, Italy, p33.

Koffi AN. and Bamba Y, 2008 " Plan de compétitivité de la filière anacarde du Mali” PCDA, composante II, Bamako, Mali“", 63 p.

Jaouadi W, Hamrouni L, Souayeh N. and Khouja ML: 2010. Étude de la germination des graines d'Acacia tortilis sous différentes contraintes abiotiques. Biotechnol. Agron. Soc. Environ. 14 : 643652.

Krool R: 1996. Les petits fruits, Paris : Maisonneuve et Larose. 35 p.

Hamawa Y, Dona A, Kanmegne ON, Mbaye niwah C, Awono JMDK. and Mapongmetsem P M: 2019. Effet du poids de noix et de la dose d'engrais sur la germination et la croissance de l'anacardier (Anacardium occidentale L., Anacardiaceae) dans la savane guinéenne du Cameroun. Afrique Science 15:302 312.

Lefèbvre A:1966. Technologie et culture de l'anacardier à Madagascar. Revue Bois et Forêt des Tropiques, 41p.

Lefèbvre A : 1969. L'anacardier, une richesse de Madagascar, Institut Français de Recherches Fruitières Outre-Mer. Fruits - Vol . 24, no 1.

Lemaitre P, Bediye P. and Ahouari H: 2003."Diagnostic global de la filière anacarde au Bénin, projet d'amélioration et de diversification des systèmes d'exploitation" - PADSE - Financement AFD, 59 p.

Malou G : 2014."Caractérisation et germination des semences de quatre variétés de Anacardium occidentale L., Bénin jaune, Costa Rica, Henry et James", Master,
Université Assane Seck de Ziguinchor, $55 \mathrm{p}$.

Marlos Bezerra A, Claudivan de Lacerda F, Enéas Gomes F, Carlos de Abreu B. and José Prisco T: 2007. Physiology of cashew plants grown under adverse conditions, Braz. J. Plant Physiol 19: 416.

Djaha A, N'Da AA, Hala N, Edo K. and N'guessan A: 2008. Bien cultiver l'anacardier en Côte d'Ivoire. Centre National de Recherche Agronimique (CNRA).

Martin KP: 2003. Plant regeneration through direct somatic embryogenesis on seed coat explants of cashew (Anacardium occidentale L.). Scientia Horticulturae, 98: 299-304.

Martin PJ, Topper CP, Bashiru RA, Boma F, De Waal D, Harries HC, Kasuga LJ, Katanila N, Kikoka LP, Lamboll R, Maddison AC, Majule AE, Masawe PA, Millanzi KJ, Nathaniels NQ, Shomari SH, Sijaona ME. and Stathers T: 1997. Cashew nut production in Tanzania: Constraints and progress through integrated crop management. Crop Protection, 16: 5 - 14.

Massengo V, Loumouamou BW, Diakabana P. and Silou T: 2014. Ethanol production fermentation of the pulpe of BOKO " mango. International Journal of Chemical Science and Technology 4: 71-77.

Ndiaye S, Charahabil MM. and Diatta M: 2017. "Caractérisation des Plantations à Base d'anacardier dans les communes de Kaour, Goudomp et Djibanar", European Scientific Journal 10: 1857 - 7881.

Niang D: 2002."Etude de la biologie de la reproduction chez Anacardium occidentale L. (Anacardiaceae)", Diplôme d'Etudes Approfondies (DEA), Université Cheikh Anta Diop de Dakar (UCAD), 56 p.

Niang PM: 2017."Caractérisation de noix et tests de germination de six variétés de Anacardium occidentale $\mathrm{L}$ de la région de 
Sédhiou : Benin Jaune, Brésil, Henry, James, Kinta, Maram", Master, Université de Thiès - Ecole Nationale Supérieure d'Agriculture (ENSA), 40 p.

Nortcliff S and Gregory PJ: 2013.The historical development of studies on soil-plant interactions". Soil Conditions and Plant Growth “, 21 p.

O'Farrell P, Armour J. and Reid D:2000. The effect onitrogen on cashew in North Queensland: A report for the rural industries research and development corporation, RIRDC Publication No 00/24, RIRDC Project No DAQ 145A

PADEC : 2016. Enquête sur le sous-secteur de l'anacarde au Sénégal.32 p.

PASA : 1994. La production et la commercialisation des produits de l'anacarde. 2 p.

Rickson FR. and Rickson: MM:1998. The cashew nut, Anacardium occidentale (Anacardiaceae), and its perennial association with ants: extrafloral nectary location and the potential for ant defense. Am. J. Bot 85: 835-849.

Rongaed :2009. "Service d'Information et d'Accompagnement sur le Marché", 23 $\mathrm{p}$.

Silou T: 1996. Le safoutier (Dacryodes edulis), un arbre mal connu. Fruits 51: 47-60.

Soro D: 2012 Couplage de procédés membranaires pour la clarification et la concentration du jus de pomme de cajou : performances et impacts sur la qualité des produits. Thèse de doctorat, École doctorale Sciences des ProcédésSciences des Aliments. Montpellier Supagro, p. 156.

Trevian MTS, Pfundstein B, Haubner R, Würtele G, Spiegelhalder B, Bartsch H. and Owen RW: 2005. Caracterisation of alkyl phenols in cashew (Anacardium occidentale L.) products and assay of their antioxydant capacity. Food and Chemical toxicology 44: 188 - 197. 